\title{
An exploratory study of the relationship between parental attitudes and behaviour and young people's consumption of alcohol
}

\author{
Graham F Moore* ${ }^{*}$ Heather Rothwell and Jeremy Segrott
}

\begin{abstract}
Background: Concern is growing regarding frequent and excessive misuse of alcohol by young people. The average age at which young people in Europe start to drink is twelve and a half, and during the last decade, the quantity of alcohol consumed by younger adolescents in the UK has increased. Families are known to play an important role in shaping young people's alcohol misuse, although family risk and protective factors associated with misuse in a UK context are in need of further investigation.

Methods: The study used a cross-sectional design, involving secondary analyses of self-completion questionnaire responses from 6,628 secondary school children (i.e. aged 11-16 years), from 12 schools within an urban location in Wales. Items relating to family functioning and perceived parental attitudes were first subjected to factor analysis. Associations of family closeness and conflict, parental monitoring and attitudes and family history of substance misuse with children's self reported alcohol consumption were examined using logistic regression analyses.

Results: Approximately three quarters of respondents reported having tried alcohol, most of whom had first tried alcohol aged 12 or under. Parental monitoring and family closeness were positively correlated with one another and were both associated with significantly lower levels of drinking behaviours. Family violence and conflict, more liberal parental attitudes towards substance use and towards alcohol and petty crime, and family history of substance misuse were positively correlated with one another and with higher levels of drinking behaviours. Parental monitoring was identified as the family functioning factor most consistently associated with drinking behaviour in multivariate analyses.

Conclusions: Significant relationships were found between young people's drinking behaviours and perceptions of risk and protective factors in the family environment. Parental monitoring was strongly associated with family closeness and appeared to form one part of a parenting style of more general communication and regulation of children's behaviour. Findings support the need for alcohol misuse prevention interventions which address risk and protective factors within the family setting. Timing of such prevention work should be related both to the development of family relationships and the age at which young people begin drinking alcohol.
\end{abstract}

\section{Background}

The risk of alcohol-related harm in adult life is inversely related to the age at which individuals begin to drink alcohol [1-3]. During recent years concern has grown regarding frequent and excessive misuse of alcohol by young people $[4,5]$. The average age at which young people in Europe start to drink is twelve and a half [6] and

* Correspondence: MooreG@cardiff.ac.uk

${ }^{1}$ Cardiff Institute of Society and Health, Cardiff School of Social Sciences, Cardiff University, 1-3 Museum Place, Cardiff, CF10 3BD UK

Full list of author information is available at the end of the article during the last decade, the quantity of alcohol consumed by younger adolescents in the UK has increased [7]. Of the forty countries taking part in the 2005/2006 European Health Behaviour in School Children (HBSC) survey, Wales had the highest proportion of 13 year-olds (26\% of girls and 27\% of boys) who had been drunk at least twice. Wales was also in the top 13 countries for weekly drinking at ages 11 ( $4 \%$ of girls and $7 \%$ of boys), 13 (20\% of girls and $23 \%$ of boys) and 15 (38\% of girls and $42 \%$ of boys), and for reporting of having first become drunk at age 13 
or younger (21\% of girls and $25 \%$ of boys aged 15$)$ [8]. Prevention of alcohol-related harm must therefore address influences on children which lead them to begin drinking early in life.

In the UK, measures to prevent alcohol misuse amongst children usually involve school-based education about alcohol and substance misuse [9-11]. There is little evidence however that programmes based solely upon classroom-based learning have been effective in changing behaviour [12]. Thus recent attention has focused on understanding family influences on young people's drinking. Family relationships and interactions are central influences on children's behaviour [13-15], and have been shown, mostly in US based studies, to influence the timing of young people's alcohol use [16]. Parental involvement and intervention at primary-school age, when family influences are relatively strong, have been identified as important in increasing the effectiveness of programmes to prevent alcohol misuse [17-21]. However, despite high levels of alcohol misuse among Welsh schoolchildren, few studies have explored family risk and protective factors for alcohol consumption in Wales or the UK.

One theoretical model for understanding potential influences of family functioning upon children's behaviours is the Social Development Model (SDM) [22]. SDM uses ideas from social control, social learning and differential association theory (which postulates that the skills, attitudes and values relating to anti-social behaviour are learned through interaction with others) [23,24] and allows for the changing weight of social influences through the life course. For example, whilst the principal influence on very young children would typically be the family, peers also become important in shaping older children's behaviour. Where children perceive limited closeness to family members, influence from peers may become greater than that of family members [25]. SDM hypothesises that social behaviour is learned through interactions with others, resulting in formation of attachments which may have a lasting effect on behaviour, through supporting development of skills, norms and values. Attachment to others who offer opportunities for and reward prosocial behaviour protects against antisocial behaviour, whilst attachment to those who provide opportunities and rewards for antisocial behaviour is a key risk factor [23,24,26].

One key protective factor commonly studied in relation to children's substance misuse is parental monitoring. Parental monitoring is usually defined as parents' knowledge of the whereabouts and associates of their children, and is related to rule-setting (e.g. about what time young people should return home) [14]. SDM categorises monitoring as a type of "external constraint" on young people's behaviour [24]. Parental monitoring has been shown to protect against adolescent alcohol misuse [27], and may be a necessary but not sufficient condition for influencing children's behaviour [14]. However, rather than a one-way process, Dishion and McMahon see parental monitoring as integral to an ongoing positive relationship between parent and child and as closely linked to the quality of parent-child relationships [28]. Indeed, some Swedish research suggests that 'monitoring' is a misnomer, with the most important factor increasing parents' awareness of their children's social activities being disclosure by children. Rather than a product solely of parental surveillance, disclosure emerges from a reciprocal process between parents and children [29]. Research with Mexican families found that more time spent with the family resulted in more parental monitoring, supporting the view that effective monitoring is a product of other family interactions.

Rule-setting and monitoring which does not arise out of close interaction may have the opposite effect from that intended. Indeed, one recent intervention which encouraged parents to set clearer rules and actively monitor children's activities led to increased family conflict, perhaps due to a focus upon surveillance in isolation from other family interactions [30]. It is likely that the specific focus on discouraging substance misuse led to introduction of rule setting and monitoring which was incongruent with usual styles of parenting. Associations of parental monitoring with children's drinking behaviour therefore cannot be understood in isolation and analyses of its impacts clearly need to take into account related risk and protective factors.

Family conflict and closeness are respectively key risk and protective factors which have been shown to be associated with substance misuse and other antisocial behaviour [31-33]. Family conflict has been linked to adolescent alcohol misuse either directly [34], or through reducing effectiveness of parental monitoring [35]. Parental attitudes favouring antisocial behaviour are known to increase the risk that children will behave antisocially $[15,36]$, likely including alcohol misuse given that the latter is closely linked to other kinds of antisocial behaviour [37]. Indeed, adolescents' misuse of alcohol and other substances has been found to be strongly related to perceptions of parental attitudes towards substance misuse [38]. Some studies have suggested that parents' non-permissive attitude towards drugs may be more influential than their own misuse of drugs [39], although one found that actual behaviour and family structure were better predictors of adolescent alcohol misuse [40]. Having a family member who misuses alcohol is a risk factor for children themselves misusing alcohol or other substances [41,42], whilst having siblings who misuse alcohol or engage in other antisocial behaviour is a particularly strong risk factor [43-45]. One study suggests 
that rather than direct modelling however, impacts of substance misuse amongst family members occur due to the higher levels of conflict and poorer parent-child relationships in families where one or more members misuse alcohol or other substances [46].

The aims of this study are to examine children's perceptions of protective (parental monitoring, family closeness) and risk factors (conflict, liberality of parental attitudes towards antisocial behaviours and family history of substance misuse) within their family environment, the extent to which these factors are associated with one another, and the associations of these risk and protective factors with children's self reported drinking behaviour. The study was commissioned by a city council's Children and Young People Strategy Unit, who aimed to use a dataset collected from a survey of twelve local schools as a basis for informing practice and policymaking in the field of alcohol misuse prevention. To our knowledge, the study is the first large scale analysis of relationships between these factors and children's drinking behaviours using data from a population in Wales, and is one of a relatively small number of UK studies contributing to the much larger body of research based mainly in the United States.

\section{Methods}

Background

The survey was conducted by Communities that Care (CTC), a community development organisation focusing upon risk and preventative factors in young people's social environments for a range of behavioural and wellbeing outcomes [47]. The study involved secondary data analysis of a de-identified cross-sectional dataset provided by CTC, collected in schools in 2008. The study was exempted from ethical review given that data were fully deidentified [48].

\section{Sampling}

All 16 schools within a single Urban district in Wales, UK were invited to participate. The survey was completed by a total of 6,628 pupils in years 7 to 11 (i.e. aged 11-16 years) attending 12 state-maintained secondary schools.

\section{Data collection procedures}

Standardised guidelines for administration of the CTC Youth Survey are reported elsewhere [49]. In brief, teachers were provided with questionnaires to administer to children during school times. Schools were provided with letters to send home to parents to make them aware of the survey, and teachers highlighted to children that participation was voluntary, offering children the opportunity to opt out. Teachers were asked to administer the questionnaires under examination conditions to mini- mise conferring. Sealable envelopes were provided for children to place their completed and anonymised questionnaires in, before these were returned to researchers.

\section{Measures \\ Children's alcohol consumption behaviours}

Children were asked several questions about alcohol consumption behaviours which formed dependent variables for this study. The first was simply 'Have you ever had more than a sip or two of an alcoholic drink?' requiring a yes or no response. Children who reported trying alcohol were then asked 'How many times have you drunk alcohol in the last 4 weeks?' and 'In the last four weeks, how many times have you had five or more alcoholic drinks in a row?', with response options of never, 1-2, 3-5, 6-9, 10 19 or 20 or more. Children who reported trying alcohol were asked to indicate whether they were frequent drinkers (i.e. 'Do you drink alcohol frequently, that is, at least once a week?'), and whether they had ever been seriously drunk.

\section{Family functioning}

The questionnaire contained 18 items relating to family functioning, all measured on a 4 point likert-scale (labelled 'NO!', 'no', 'yes', 'YES!') to indicate varying levels of agreement with each statement. A rotated factor solution from factor analysis of these 18 items presented in Table 1 indicates 4 distinct factors emerging from these items. Factors were labelled 'parental monitoring', 'family closeness', 'family conflict' and 'family violence'. The first two factors were considered protective factors, whilst family conflict and violence were considered risk factors. Factor loadings of less than 0.5 are suppressed (i.e. automatically deleted) to aid readability. All four factors demonstrated acceptable internal consistency, with Cronbach's alpha coefficients of 0.80 for parental monitoring, 0.79 for family closeness, 0.77 for family conflict and 0.82 for family violence.

\section{Children's perceptions of parental attitudes towards 'deviant' behaviours}

The questionnaire contained 9 items on perceptions of parental beliefs regarding how wrong it would be for them (the child) to engage in a range of behaviours, all measured on a 4 point likert-scale (from 'very wrong' to 'not wrong at all'). The rotated factor solution presented in Table 2 illustrates the two factors emerging from these items. These factors were labelled i) parental attitudes towards alcohol and petty crime, and ii) parental attitudes towards substance misuse. The item regarding under-age pregnancy did not load onto either factor and was dropped from analysis. Both factors demonstrated acceptable internal consistency (Parental attitudes to alcohol and petty crime $\alpha=.78$; Parental attitudes to substance misuse $\alpha=.74$ ). 
Table 1: Rotated factor solution* from factor analysis of 18 items relating to family functioning

\begin{tabular}{|c|c|c|c|c|}
\hline & $\begin{array}{l}\text { Factor } 1 \text { (Parental } \\
\text { monitoring) }\end{array}$ & $\begin{array}{l}\text { Factor } 2 \text { (Family } \\
\text { closeness) }\end{array}$ & $\begin{array}{l}\text { Factor } 3 \text { (Family } \\
\text { conflict) }\end{array}$ & $\begin{array}{l}\text { Factor } 4 \text { (Family } \\
\text { violence) }\end{array}$ \\
\hline $\begin{array}{l}\text { My family has clear } \\
\text { rules about alcohol } \\
\text { and using drugs }\end{array}$ & .61 & & & \\
\hline $\begin{array}{l}\text { If I drank some alcohol } \\
\text { without my parents' } \\
\text { permission, I would be } \\
\text { caught by my parents }\end{array}$ & .67 & & & \\
\hline $\begin{array}{l}\text { If I played truant from } \\
\text { school, I would be } \\
\text { caught by my parents }\end{array}$ & .61 & & & \\
\hline $\begin{array}{l}\text { The rules in my family } \\
\text { are clear }\end{array}$ & .66 & & & \\
\hline $\begin{array}{l}\text { My parents want me to } \\
\text { phone if I'm going to } \\
\text { be late getting home }\end{array}$ & .59 & & & \\
\hline $\begin{array}{l}\text { My parents ask me } \\
\text { regularly if I've done } \\
\text { my homework }\end{array}$ & .54 & & & \\
\hline $\begin{array}{l}\text { When I'm not at home, } \\
\text { one of my parents } \\
\text { knows where I am and } \\
\text { who I am with }\end{array}$ & .61 & & & \\
\hline $\begin{array}{l}\text { My parents would } \\
\text { know if I didn't come } \\
\text { home on time }\end{array}$ & .61 & & & \\
\hline
\end{tabular}

lo

fun things with them

My parents ask me

what I think before

family decisions

affecting me are made

If I had a personal

problem, I could ask

my parents for help

How often do your

parents tell, or show

you that they are

proud of you?

How often do your

parents notice when

you are doing

something well?

People in my family

often insult or yell at

each other

People in my family

have serious

arguments 
Table 1: Rotated factor solution* from factor analysis of 18 items relating to family functioning (Continued)

\begin{tabular}{l} 
We argue about the \\
same things in my \\
family over and over \\
again \\
\hline Adults in my home \\
sometimes try to hurt \\
me, for example by \\
kicking, hitting or \\
pushing me \\
Adults in my home \\
sometimes try to hurt \\
each other, for \\
example by kicking, \\
hitting or pushing \\
each other
\end{tabular}

${ }^{*}$ factor loadings $<0.50$ are suppressed (i.e. automatically deleted from the table)

\section{Family history of alcohol or substance misuse}

The questionnaire contained two items regarding family history of alcohol or substance misuse. The first asked 'Did any of your brothers or sisters drink alcohol frequently before the age of 18?' Three response options were available; yes, no, or 'I don't have any brothers or sisters'. As the present study was interested in whether or not children reported having siblings who modelled alcohol misuse before the age of 18 , this was converted into a dichotomous variable, comparing those who said yes (i.e. did have siblings who modelled alcohol misuse behaviours) with those who gave another response (i.e. did not have siblings or had siblings who did not model alcohol misuse behaviours). The second item was 'Has any member of your family ever had a serious substance misuse problem?' with response options of yes or no.

Age of first trying alcohol

Children were asked to indicate how old they were when they first tried alcohol. Response options were 10 or younger, $11,12,13,14,15$ or 16 years.

Demographic covariates

Children were asked to indicate their year group and gender on the questionnaire. These details were used as

Table 2: Rotated factor solution* including items relating to perceptions of parental attitudes towards 'deviant' behaviours

\begin{tabular}{|c|c|c|}
\hline $\begin{array}{l}\text { How wrong do your parents feel it } \\
\text { would be for you to: }\end{array}$ & $\begin{array}{c}\text { Factor } 1 \\
\text { (Parental attitudes to alcohol and petty } \\
\text { crime) }\end{array}$ & $\begin{array}{c}\text { Factor } 2 \text { (Parental attitudes to } \\
\text { substance use) }\end{array}$ \\
\hline Steal something & 69 & \\
\hline Pick a fight with someone & .78 & \\
\hline $\begin{array}{l}\text { Draw graffiti on buildings without } \\
\text { permission }\end{array}$ & .72 & \\
\hline Drink alcohol regularly & .64 & \\
\hline Play truant from school & .62 & \\
\hline Smoke cigarettes & & .60 \\
\hline Smoke cannabis & & .88 \\
\hline Use drugs like ecstasy. LSD or cocaine & & .89 \\
\hline
\end{tabular}

Become pregnant, or get someone pregnant** $^{* *}$

*factor loadings $<0.50$ are suppressed (i.e. automatically deleted from the table)

**item dropped due to loading on neither factor 
covariates in multivariate analyses, with year group used as a proxy for age.

\section{Analysis}

Summated scales were constructed to represent the independent variables identified by factor analyses above, through summing values for all items relating to each scale and dividing by the number of items. In order to minimise data loss, where items were missing, these were imputed with the mean value for all remaining items. Data were excluded if less than half of items for a scale were completed.

In order to explore interrelatedness of ordinal independent variables, these were correlated using Spearman's Rank Correlation. This was favoured over Pearson's Product Moment correlation due to the skewed nature of all family functioning variables, with risk factors positively skewed whilst protective factors were negatively skewed. Associations of ordinal independent variables with binary independent variables (family history items) were assessed using Mann Whitney U-tests.

Dependent variables were the binary or ordinal items relating to children's drinking behaviours. Univariable associations of all independent variables with binary dependent variables, (i.e. 'Have you ever had more than a sip or two of an alcoholic drink?' and 'Do you drink alcohol frequently, that is, at least once a week?') were assessed using univariable binary logistic regression. For items forming ordinal dependent variables ('How many times have you drunk alcohol in the last 4 weeks' and 'In the last four weeks, how many times have you had five or more alcoholic drinks in a row?), due to small numbers in the higher ends of the distributions, these were condensed into three category ordinal items (i.e. never, 1-2 times or $3+$ times). Due to violation of the proportional odds assumption, ordinal dependent variables were examined using multinomial logistic regression, with the largest group ('never') set as the base category. Subsequent multivariable models were constructed in two stages. First, protective factors were entered (i.e. parental monitoring and family closeness), before risk factors were entered alongside significant protective factors. Multivariate models adjusted for age, sex and age of first drinking alcohol. Although the data sample was hierarchical, clustering at the school level could not be accounted for in these analyses, due to removal of school IDs by the owners of the dataset.

\section{Results}

\section{Response rates}

Twelve out of 16 (75\%) schools agreed to take part, although 2 excluded year 7 children, and 2 excluded years 7 and 8 , considering questions inappropriate for younger children. Return rates for the 8 schools including all year groups ranged from 40 to $89 \%$ (Mean $=70 \%$ SD $=19 \%$ ). For the two schools excluding years 7 and 8, return rates were $36 \%$ and $42 \%$. For the two schools excluding year 7 children only, return rates were $49 \%$ and $63 \%$. The mean response rate for all 12 schools was 64\% (SD = 19\%). Whilst 6,628 children provided data, analyses focused upon children within school years 7 to 11 (i.e. aged 11-16 years), leading to the exclusion of 117 children who reported either being in year 6, year 12, or who provided no year group details. Hence, 6511 children who provided data were eligible for inclusion, of whom 6125 responded to a question on whether they had tried alcohol. Many analyses however focused specifically on a subsample of 4634 children who reported having tried alcohol.

For the construction of regression models, the dataset was limited to children who provided responses for all independent variables and the dependent variable in question. Chi-squared analyses comparing children providing complete or missing data for regression models in relation to the first dependent variable (i.e. 'trying alcohol') indicated that complete data were slightly less likely to be available for boys than girls $\left(75.3 \%\right.$ vs $79.7 \%$ : $\chi^{2}=$ 17.3, $\mathrm{p}<0.001$ ), and for children in the younger 3 age groups compared to the older $2\left(74.9 \%\right.$ vs $77.3 \% \chi^{2}=4.7$, $\mathrm{p}<0.05)$.

\section{Sample description}

Among the whole sample, 3225 (50.7\%) children were male. Amongst the subsample of children who reported having tried alcohol, 2223 (49.2\%) were male. The whole sample contained 1196 (18.4\%) Year 7 pupils, 1164 (17.9\%) Year 8 pupils, 1472 (22.6\%) Year 9 pupils, 1432 (22.0\%) Year 10 pupils and 1248 (19.2) Year 11 pupils. Of children who had tried alcohol, $562(12.1 \%)$ were in Year 7, $723(15.6 \%)$ were in Year 8, 1083 (23.4\%) were in Year 9, 1193 (25.7\%) were in Year 10 and 1073 (23.2\%) were in Year 11 .

\section{Drinking behaviours of 11-16 year olds}

As demonstrated in Table 3, approximately three-quarters of children reported having tried alcohol. Of these children, most (65.9\%) first tried alcohol aged 12 or younger. Most children who had tried alcohol (66.9\%) reported having drunk alcohol at least once in the past 4 weeks, though for most of these children, this was only once or twice. In total, $28.2 \%$ of children reported drinking alcohol 3 or more times in the past 4 weeks. Most who had tried alcohol reported that they had not binge drunk in the past four weeks (62.7\%). Of the remaining children, $22.9 \%$ had binge drunk once or twice in this time period, and the remaining $14.3 \%$ had binge drunk 3 or more times. Of children who had tried alcohol, $18.8 \%$ classed themselves as frequent drinkers, whilst $39.4 \%$ reported that they had been seriously drunk. 
Table 3: Frequencies of alcohol consumption behaviours amongst secondary school children

\begin{tabular}{|c|c|c|c|}
\hline & & Frequency & Percent \\
\hline \multirow{2}{*}{$\begin{array}{l}\text { Have you ever had more than } \\
\text { a sip or two of an alcoholic } \\
\text { drink? }\end{array}$} & Yes & 4634 & 75.7 \\
\hline & No & 1491 & 24.3 \\
\hline \multirow{7}{*}{$\begin{array}{l}\text { How old were you when you } \\
\text { first had more than a sip or } \\
\text { two of an alcoholic drink? } \\
\text { (only answered if yes to 1) }\end{array}$} & 10 or younger & 1054 & 22.9 \\
\hline & 11 & 1061 & 23.1 \\
\hline & 12 & 917 & 19.9 \\
\hline & 13 & 837 & 18.2 \\
\hline & 14 & 520 & 11.3 \\
\hline & 15 & 186 & 4.0 \\
\hline & 16 & 23 & .5 \\
\hline \multirow{6}{*}{$\begin{array}{l}\text { How many times have you } \\
\text { drunk alcohol in the last four } \\
\text { weeks? (only answered if yes } \\
\text { to 1) }\end{array}$} & Never & 1508 & 33.1 \\
\hline & $1-2$ times & 1767 & 38.8 \\
\hline & 3-5 times & 819 & 18.0 \\
\hline & 6-9 times & 267 & 5.9 \\
\hline & 10-19 times & 108 & 2.4 \\
\hline & 20 or more times & 85 & 1.9 \\
\hline \multirow{6}{*}{$\begin{array}{l}\text { In the last four weeks, how } \\
\text { many times have you had five } \\
\text { or more alcoholic drinks in a } \\
\text { row? (only answered if yes to } \\
\text { 1) }\end{array}$} & Never & 2847 & 62.7 \\
\hline & 1-2 times & 1042 & 22.9 \\
\hline & 3-5 times & 423 & 9.3 \\
\hline & 6-9 times & 134 & 2.9 \\
\hline & 10-19 times & 46 & 1.0 \\
\hline & 20 or more times & 52 & 1.1 \\
\hline \multirow{2}{*}{$\begin{array}{l}\text { Do you drink alcohol } \\
\text { frequently, that is, at least } \\
\text { once a week? (only answered } \\
\text { if yes to 1) }\end{array}$} & Yes & 845 & 18.8 \\
\hline & No & 3656 & 81.2 \\
\hline \multirow{2}{*}{$\begin{array}{l}\text { Have you ever been seriously } \\
\text { drunk? (only answered if yes } \\
\text { to 1) }\end{array}$} & Yes & 1739 & 39.4 \\
\hline & No & 2677 & 60.6 \\
\hline
\end{tabular}




\section{Associations between independent variables}

As demonstrated in Table 4, there was a high degree of interrelationship among the different components of family functioning, with 'protective factors' (i.e. family closeness, parental monitoring) positively correlated with one another, and negatively correlated with 'risk factors' (i.e. family conflict and violence, and liberality of attitudes towards alcohol/petty crime and substance use). For binary independent variables, Mann-Whitney U tests, indicated that children who reported having siblings who drank regularly before the age of 18 reported significantly lower levels of parental monitoring $(\mathrm{z}=-19.4)$ and family closeness $(\mathrm{z}=-13.3)$, higher levels of family conflict $(\mathrm{z}=$ $12.7)$ and violence $(\mathrm{z}=-7.5)$, and more liberal parental attitudes to alcohol and petty crime $(\mathrm{z}=-14.7)$ and substance misuse $(z=-14.6)$. Similarly, children reporting having a family member with a substance misuse problem reported significantly lower levels of parental monitoring $(\mathrm{z}=-11.6)$ and family closeness $(\mathrm{z}=-10.7)$, higher levels of family conflict $(z=-13.1)$ and violence $(z=-13.0)$ and more liberal parental attitudes to alcohol and petty crime $(\mathrm{z}=-13.0)$ and substance misuse $(\mathrm{z}=-11.4)$. P-values for all tests of difference were below 0.01 .

\section{Associations between independent variables and children's self reported drinking behaviour}

In univariable analyses (see Table 5), both protective factors (parental monitoring and family closeness) were negatively associated with drinking behaviours, so that as either factor increased, all markers of children's drinking behaviour became less likely. The inverse was observed for family conflict and family violence, with an increase in either of these variables associated with increases in the likelihood of all markers of drinking behaviour. As parental attitudes towards substance misuse and towards alcohol and petty crime became more liberal, drinking behaviours became significantly more likely. Significant increases in likelihood of all markers of drinking behaviours were observed for children reporting having a sibling who drank regularly before the age of 18 or a family member with a history of substance misuse problems.

Multivariate models were constructed in two stages; first considering protective factors and then risk factors. Entry of parental monitoring and family closeness into a single model in step 1 led to associations of family closeness with children's self-reported drinking behaviours becoming non-significant in all cases with the exception of a marginal association with self classification as a frequent drinker, suggesting that univariable association of family closeness with self-reported drinking behaviours were explained by the strong relationship between family closeness and parental monitoring (see Table 4). Step 2 therefore excluded family closeness, and combined parental monitoring with hypothesised risk factors. After entry of risk factors, parental monitoring remained consistently and inversely associated with all markers of drinking behaviour. Whilst family conflict remained a significant predictor of whether the child had tried alcohol, remaining associations with drinking behaviour became non-significant. All associations of family violence with consumption behaviours became non-significant. Hence, family conflict and violence, whilst

Table 4: Spearman's rank correlation coefficients for all ordinal variables of interest $(n=4977)$

\begin{tabular}{|c|c|c|c|c|c|c|}
\hline & $\begin{array}{c}\text { Parental } \\
\text { monitoring }\end{array}$ & $\begin{array}{l}\text { Family } \\
\text { conflict }\end{array}$ & $\begin{array}{c}\text { Family } \\
\text { violence }\end{array}$ & $\begin{array}{c}\text { Family } \\
\text { closeness }\end{array}$ & $\begin{array}{c}\text { Parent } \\
\text { attitudes to } \\
\text { substance } \\
\text { misuse }\end{array}$ & $\begin{array}{l}\text { Parent } \\
\text { attitudes to } \\
\text { alcohol and } \\
\text { petty crime }\end{array}$ \\
\hline $\begin{array}{l}\text { Age (school } \\
\text { year) }\end{array}$ & $-.34^{* *}$ & $.06^{* *}$ & .02 & $-.23^{* *}$ & $.24^{* *}$ & $.25^{* *}$ \\
\hline $\begin{array}{l}\text { Parent } \\
\text { attitudes to } \\
\text { alcohol and } \\
\text { petty crime }\end{array}$ & $-.55^{* *}$ & $.23^{* *}$ & $.19^{* *}$ & $-.38^{* *}$ & $.42^{* *}$ & \\
\hline $\begin{array}{l}\text { Parent } \\
\text { attitudes to } \\
\text { substance } \\
\text { misuse }\end{array}$ & $-.38^{* *}$ & $.16^{* *}$ & $.17^{* *}$ & $-.25^{* *}$ & & \\
\hline $\begin{array}{l}\text { Family } \\
\text { closeness }\end{array}$ & $.53^{* *}$ & $-.38^{* *}$ & $-.32^{* *}$ & & & \\
\hline $\begin{array}{l}\text { Family } \\
\text { violence }\end{array}$ & $-.23^{* *}$ & $.39 * *$ & & & & \\
\hline Family conflict & $-.27^{* *}$ & & & & & \\
\hline
\end{tabular}

${ }^{*}$ sig at $5 \%,{ }^{* *}$ sig at $1 \%$ 
Table 5: Odds ratios from logistic regression analyses (binary and multinomial) examining associations of family functioning with children's self-reported alcohol consumption $\left({ }^{*} p<0.05,{ }^{* *} p<0.01,{ }^{* * *} p<0.001\right)$

\begin{tabular}{|c|c|c|c|c|c|c|c|}
\hline & \multirow{2}{*}{$\begin{array}{l}\text { Ever tried } \\
\text { alcohol (n } \\
=4977)\end{array}$} & \multirow{2}{*}{$\begin{array}{l}\text { Frequent } \\
\text { drinker (n } \\
=3651)\end{array}$} & \multirow{2}{*}{$\begin{array}{c}\text { Ever been } \\
\text { seriously } \\
\text { drunk }(n= \\
3594)\end{array}$} & \multicolumn{2}{|c|}{$\begin{array}{c}\text { Drunk alcohol in past } 4 \\
\text { weeks }(n=3697)\end{array}$} & \multicolumn{2}{|c|}{$\begin{array}{l}\text { Binge drunk in last } 4 \text { weeks } \\
\qquad(n=3687)\end{array}$} \\
\hline & & & & 1-2 times & $\begin{array}{l}\text { More than } \\
\text { twice }\end{array}$ & 1-2 times & $\begin{array}{l}\text { More than } \\
\text { twice }\end{array}$ \\
\hline \multicolumn{8}{|c|}{ Univariable associations } \\
\hline $\begin{array}{l}\text { Family } \\
\text { closeness }\end{array}$ & $\begin{array}{c}0.51^{* * *} \\
(0.46 \text { to } \\
0.56)\end{array}$ & $\begin{array}{c}0.49 * * * \\
(0.44 \text { to } \\
0.54)\end{array}$ & $\begin{array}{c}0.54^{* * *} \\
(0.49 \text { to } \\
0.59)\end{array}$ & $\begin{array}{c}0.73^{* * *} \\
(0.65 \text { to } \\
0.82)\end{array}$ & $\begin{array}{c}0.48^{* * *} \\
(0.43 \text { to } \\
0.54)\end{array}$ & $\begin{array}{c}0.60^{* * *} \\
(0.54 \text { to } \\
0.67)\end{array}$ & $\begin{array}{c}0.45^{* * *} \\
(0.40 \text { to } \\
0.51)\end{array}$ \\
\hline $\begin{array}{l}\text { Parental } \\
\text { monitoring }\end{array}$ & $\begin{array}{c}0.16^{* * *} \\
(0.140 .19)\end{array}$ & $\begin{array}{c}0.19 * * * \\
(0.16 \text { to } \\
0.23)\end{array}$ & $\begin{array}{c}0.22^{* * *} \\
(0.19 \text { to } \\
0.25)\end{array}$ & $\begin{array}{c}0.32^{* * *} \\
(0.27 \text { to } \\
0.38)\end{array}$ & $\begin{array}{c}0.11^{* * *} \\
(0.09 \text { to } \\
0.13)\end{array}$ & $\begin{array}{c}0.24^{* * *} \\
(0.20 \text { to } \\
0.28)\end{array}$ & $\begin{array}{c}0.11^{* * *} \\
(0.09 \text { to } \\
0.13)\end{array}$ \\
\hline Family conflict & $\begin{array}{c}1.63^{* * *} \\
(1.50 \text { to } \\
1.78)\end{array}$ & $\begin{array}{c}1.42^{* * *} \\
(1.29 \text { to } \\
1.57)\end{array}$ & $\begin{array}{c}1.38^{* * *} \\
(1.27 \text { to } \\
1.50)\end{array}$ & $\begin{array}{c}1.28^{* *} \\
(1.16 \text { to } \\
1.40)\end{array}$ & $\begin{array}{c}1.51^{* * *} \\
(1.36 \text { to } \\
1.67)\end{array}$ & $\begin{array}{c}1.24^{* * *} \\
(1.12 \text { to } \\
1.36)\end{array}$ & $\begin{array}{c}1.40^{* * *} \\
(1.25 \text { to } \\
1.57)\end{array}$ \\
\hline $\begin{array}{l}\text { Family } \\
\text { violence }\end{array}$ & $\begin{array}{c}1.46^{* * *} \\
(1.26 \text { to } \\
1.69)\end{array}$ & $\begin{array}{c}1.70^{* * *} \\
(1.49 \text { to } \\
1.94)\end{array}$ & $\begin{array}{c}1.42^{* * *} \\
(1.26 \text { to } \\
1.60)\end{array}$ & $\begin{array}{c}1.20^{*} \\
(1.03 \text { to } \\
1.40)\end{array}$ & $\begin{array}{c}1.57^{* * *} \\
(1.37 \text { to } \\
1.85)\end{array}$ & $\begin{array}{c}1.34^{* * *} \\
(1.16 \text { to } \\
1.55)\end{array}$ & $\begin{array}{c}1.77^{* * *} \\
(1.53 \text { to } \\
2.06)\end{array}$ \\
\hline $\begin{array}{l}\text { Parental } \\
\text { attitudes to } \\
\text { substance } \\
\text { misuse }\end{array}$ & $\begin{array}{c}4.68^{* * *} \\
\text { (3.35 to } \\
6.54)\end{array}$ & $\begin{array}{c}4.47^{* * *} \\
(3.70 \text { to } \\
5.41)\end{array}$ & $\begin{array}{c}4.12^{* * *} \\
(3.34 \text { to } \\
5.07)\end{array}$ & $\begin{array}{c}2.83^{* * *} \\
(2.06 \text { to } \\
3.90)\end{array}$ & $\begin{array}{c}8.30^{* * *} \\
(6.06 \text { to } \\
11.35)\end{array}$ & $\begin{array}{c}5.92^{* * *} \\
(4.58 \text { to } \\
7.64)\end{array}$ & $\begin{array}{c}10.85^{* * *} \\
(8.32 \text { to } \\
14.14)\end{array}$ \\
\hline $\begin{array}{l}\text { Parental } \\
\text { attitudes - } \\
\text { alcohol petty } \\
\text { crime }\end{array}$ & $\begin{array}{c}4.50 * * * \\
(3.77 \text { to } \\
5.38)\end{array}$ & $\begin{array}{c}3.60^{* * *} \\
(3.08 \text { to } \\
4.20)\end{array}$ & $\begin{array}{c}2.98^{* * *} \\
(2.60 \text { to } \\
3.42)\end{array}$ & $\begin{array}{c}2.21^{* * *} \\
(1.86 \text { to } \\
2.62)\end{array}$ & $\begin{array}{c}4.80^{* * *} \\
(4.00 \text { to } \\
5.76)\end{array}$ & $\begin{array}{c}3.01^{* * *} \\
(2.56 \text { to } \\
3.53)\end{array}$ & $\begin{array}{c}5.41^{* * *} \\
(4.50 \text { to } \\
6.50)\end{array}$ \\
\hline $\begin{array}{l}\text { Brothers or } \\
\text { sisters drank } \\
\text { frequently }\end{array}$ & $\begin{array}{c}5.59 * * * \\
(4.56 \text { to } \\
6.85)\end{array}$ & $\begin{array}{c}2.94^{* * *} \\
(2.48 \text { to } \\
3.47)\end{array}$ & $\begin{array}{c}2.64^{* * *} \\
(2.30 \text { to } \\
3.04)\end{array}$ & $\begin{array}{c}1.89^{* * *} \\
(1.60 \text { to } \\
2.24)\end{array}$ & $\begin{array}{c}3.78^{* * *} \\
(3.16 \text { to } \\
4.51)\end{array}$ & $\begin{array}{c}2.76^{* * *} \\
(2.35 \text { to } \\
3.24)\end{array}$ & $\begin{array}{c}3.31^{* * *} \\
(2.74 \text { to } \\
3.01)\end{array}$ \\
\hline $\begin{array}{l}\text { Family } \\
\text { member } \\
\text { substance } \\
\text { problem }\end{array}$ & $\begin{array}{c}3.15^{* * *} \\
(2.48 \text { to } \\
4.00)\end{array}$ & $\begin{array}{c}2.43^{* * *} \\
(2.01 \text { to } \\
2.93)\end{array}$ & $\begin{array}{c}2.61 * * * \\
(2.21 \text { to } \\
3.10)\end{array}$ & $\begin{array}{c}1.32^{*} \\
(1.07 \text { to } \\
1.62)\end{array}$ & $\begin{array}{c}2.21^{* * *} \\
(1.79 \text { to } \\
2.73)\end{array}$ & $\begin{array}{c}1.81 * * * \\
(1.51 \text { to } \\
2.24)\end{array}$ & $\begin{array}{c}2.77^{* * *} \\
(2.23 \text { to } \\
3.43)\end{array}$ \\
\hline \multicolumn{8}{|c|}{ Multivariate analysis - Protective factors } \\
\hline $\begin{array}{l}\text { Family } \\
\text { closeness }\end{array}$ & $\begin{array}{c}0.97 \\
(0.86 \text { to } \\
1.09)\end{array}$ & $\begin{array}{c}0.86^{*} \\
(0.75 \text { to } \\
0.98)\end{array}$ & $\begin{array}{c}0.91 \\
(0.81 \text { to } \\
1.03)\end{array}$ & $\begin{array}{c}1.08 \\
(0.95 \text { to } \\
1.22)\end{array}$ & $\begin{array}{c}1.06 \\
(0.91 \text { to } \\
1.22)\end{array}$ & $\begin{array}{c}0.98 \\
(0.86 \text { to } \\
1.12)\end{array}$ & $\begin{array}{c}0.97 \\
(0.82 \text { to } \\
1.14)\end{array}$ \\
\hline $\begin{array}{l}\text { Parental } \\
\text { monitoring }\end{array}$ & $\begin{array}{c}0.23^{* * *} \\
(0.19 \text { to } \\
0.28)\end{array}$ & $\begin{array}{c}0.27^{* * *} \\
(0.22 \text { to } \\
0.33)\end{array}$ & $\begin{array}{c}0.31 * * * \\
(0.26 \text { to } \\
0.37)\end{array}$ & $\begin{array}{c}0.35^{* * *} \\
(0.28 \text { to } \\
0.43)\end{array}$ & $\begin{array}{c}0.16^{* * *} \\
(0.12 \text { to } \\
0.20)\end{array}$ & $\begin{array}{c}0.29 * * * \\
(0.24 \text { to } \\
0.36)\end{array}$ & $\begin{array}{c}0.15^{* * *} \\
(0.12 \text { to } \\
0.19)\end{array}$ \\
\hline \multicolumn{8}{|c|}{ Multivariate analysis - Parental monitoring and risk factors } \\
\hline $\begin{array}{l}\text { Parental } \\
\text { monitoring }\end{array}$ & $\begin{array}{c}0.38^{* * *} \\
(0.31 \text { to } \\
0.46)\end{array}$ & $\begin{array}{c}0.41^{* * *} \\
(0.33 \text { to } \\
0.52)\end{array}$ & $\begin{array}{c}0.41^{* * *} \\
(0.34 \text { to } \\
0.50)\end{array}$ & $\begin{array}{c}0.45^{* * *} \\
(0.36 \text { to } \\
0.55)\end{array}$ & $\begin{array}{c}0.25^{* * *} \\
(0.20 \text { to } \\
0.32)\end{array}$ & $\begin{array}{c}0.43^{* * *} \\
(0.35 \text { to } \\
0.53)\end{array}$ & $\begin{array}{c}0.26^{* * *} \\
(0.20 \text { to } \\
0.34)\end{array}$ \\
\hline Family conflict & $\begin{array}{c}1.27^{* * *} \\
(1.14 \text { to } \\
1.41)\end{array}$ & $\begin{array}{c}0.92 \\
(0.79 \text { to } \\
1.07)\end{array}$ & $\begin{array}{c}1.04 \\
(0.94 \text { to } \\
1.16)\end{array}$ & $\begin{array}{c}1.14^{*} \\
(1.02 \text { to } \\
1.27)\end{array}$ & $\begin{array}{c}1.07 \\
(0.94 \text { to } \\
1.22)\end{array}$ & $\begin{array}{c}0.93 \\
(0.82 \text { to } \\
1.05)\end{array}$ & $\begin{array}{c}0.84^{*} \\
(0.72 \text { to } \\
0.98)\end{array}$ \\
\hline
\end{tabular}


Table 5: Odds ratios from logistic regression analyses (binary and multinomial) examining associations of family functioning with children's self-reported alcohol consumption $\left({ }^{*} p<0.05,{ }^{* *} p<0.01,{ }^{* *} p<0.001\right)$ (Continued)

\begin{tabular}{|c|c|c|c|c|c|c|c|}
\hline $\begin{array}{l}\text { Family } \\
\text { violence }\end{array}$ & $\begin{array}{c}.90 \\
(0.76 \text { to } \\
1.07)\end{array}$ & $\begin{array}{c}1.12 \\
(0.94 \text { to } \\
1.31)\end{array}$ & $\begin{array}{c}0.97 \\
(0.82 \text { to } \\
1.13)\end{array}$ & $\begin{array}{c}0.93 \\
(0.78 \text { to } \\
1.11)\end{array}$ & $\begin{array}{c}0.94 \\
(0.77 \text { to } \\
1.15)\end{array}$ & $\begin{array}{c}1.02 \\
(0.83 \text { to } \\
1.22)\end{array}$ & $\begin{array}{c}1.14 \\
(0.92 \text { to } \\
1.40)\end{array}$ \\
\hline $\begin{array}{l}\text { Parental } \\
\text { attitudes to } \\
\text { substance } \\
\text { misuse }\end{array}$ & $\begin{array}{c}0.79 \\
(0.58 \text { to } \\
1.08)\end{array}$ & $\begin{array}{c}1.94^{* * *} \\
(1.56 \text { to } \\
2.42)\end{array}$ & $\begin{array}{c}1.52^{* * *} \\
(1.20 \text { to } \\
1.91)\end{array}$ & $\begin{array}{c}1.20 \\
(0.86 \text { to } \\
1.68)\end{array}$ & $\begin{array}{c}2.15^{* * *} \\
(1.54 \text { to } \\
3.01)\end{array}$ & $\begin{array}{c}2.26^{* * *} \\
(1.70 \text { to } \\
2.99)\end{array}$ & $\begin{array}{c}3.05^{* * *} \\
(2.27 \text { to } \\
4.11)\end{array}$ \\
\hline $\begin{array}{l}\text { Parental } \\
\text { attitudes - } \\
\text { alcohol petty } \\
\text { crime }\end{array}$ & $\begin{array}{c}1.67^{* * *} \\
(1.34 \text { to } \\
2.09)\end{array}$ & $\begin{array}{c}1.30^{*} \\
(1.05 \text { to } \\
1.61)\end{array}$ & $\begin{array}{c}1.27^{* *} \\
(1.05 \text { to } \\
1.54)\end{array}$ & $\begin{array}{c}1.27^{* *} \\
(1.03 \text { to } \\
1.57)\end{array}$ & $\begin{array}{c}1.30^{* *} \\
(1.02 \text { to } \\
1.65)\end{array}$ & $\begin{array}{c}1.44^{* *} \\
(1.17 \text { to } \\
1.77)\end{array}$ & $\begin{array}{c}1.54^{* *} \\
(1.20 \text { to } \\
1.99)\end{array}$ \\
\hline $\begin{array}{l}\text { Brothers or } \\
\text { sisters drank } \\
\text { frequently }\end{array}$ & $\begin{array}{c}3.14^{* * *} \\
(2.53 \text { to } \\
3.91)\end{array}$ & $\begin{array}{c}1.87^{* *} \\
(1.55 \text { to } \\
2.26)\end{array}$ & $\begin{array}{c}1.69 * * * \\
(1.44 \text { to } \\
1.98)\end{array}$ & $\begin{array}{c}1.49^{* * *} \\
(1.24 \text { to } \\
1.78)\end{array}$ & $\begin{array}{c}2.32^{* *} \\
(1.84 \text { to } \\
2.76)\end{array}$ & $\begin{array}{c}1.97^{* * *} \\
(1.65 \text { to } \\
2.36)\end{array}$ & $\begin{array}{c}2.02^{* * *} \\
(1.61 \text { to } \\
2.53)\end{array}$ \\
\hline $\begin{array}{l}\text { Family } \\
\text { member with } \\
\text { substance } \\
\text { problem }\end{array}$ & $\begin{array}{c}1.72^{* * *} \\
(1.32 \text { to } \\
2.24)\end{array}$ & $\begin{array}{c}1.33^{* * *} \\
(1.06 \text { to } \\
1.67)\end{array}$ & $\begin{array}{c}1.73^{* * *} \\
(1.43 \text { to } \\
2.14)\end{array}$ & $\begin{array}{c}0.97 \\
(0.77 \text { to } \\
1.22)\end{array}$ & $\begin{array}{c}1.06 \\
(0.82 \text { to } \\
1.37)\end{array}$ & $\begin{array}{c}1.25 \\
(0.99 \text { to } \\
1.56)\end{array}$ & $\begin{array}{c}1.43^{* *} \\
(1.10 \text { to } \\
1.88)\end{array}$ \\
\hline Nagelkerke R² & 0.29 & 0.26 & 0.31 & 0.26 & & 0.32 & \\
\hline
\end{tabular}

associated with drinking behaviours in univariable analyses, did not appear to be consistent independent predictors after accounting for other factors within the model.

Parental attitudes to substance misuse remained a significant predictor of all alcohol consumption behaviours, with the exception of whether the child had tried alcohol. Parental attitudes to alcohol and petty crime remained significantly associated with all markers of drinking behaviour, with the likelihood of all drinking behaviours increasing as the child reported more liberal parental attitudes. Having a sibling who drank regularly before the age of 18 remained significantly associated with increased likelihood of all markers of alcohol consumption, whilst having a family member with a history of substance misuse problems remained a significant predictor of all alcohol consumption markers, with the exception of frequency of alcohol consumption in the past 4 weeks.

\section{Discussion}

The results of the present study are broadly consistent with evidence that while the overall prevalence of alcohol consumption among young people has fallen in recent years, the volume of alcohol consumed by some individuals has increased, with a trend towards greater alcohol consumption by younger adolescents [7]. Self-reported alcohol misuse in this survey suggests that weekly drinking was marginally less prevalent than in Wales as a whole, whilst the incidence of drunkenness was comparable. Nearly $19 \%$ of pupils aged 11-16 in this study reported drinking weekly compared with averages of $21 \%$ (girls) and 24\% (boys) of 11-15-year-olds completing the HBSC survey. In the HBSC survey, $28 \%$ of girls and $29 \%$ of boys reported having been drunk at least twice [8]. In the present study, $39 \%$ of pupils who had tried alcohol (approximately 29\% of all pupils) reported that they had been seriously drunk. This comparison should perhaps be treated with caution given that the exclusion of younger pupils in four of the twelve schools means that the CTC sample includes a larger proportion of older pupils than the HBSC sample. Nevertheless, it is clear that the survey area is not exempt from the more general concerns about the large number of young people who misuse alcohol.

Previous research has stressed the importance of effective timing of prevention activities, both in relation to development of family relationships, and young people's drinking practices [20]. The present research found that a significant proportion of young people started drinking alcohol by age 10 , and most (65.9\%) had first tried alcohol aged 12 or younger. Gruber, et al. found that young people aged 10-12 who drank were particularly vulnerable to alcohol dependency, and that delaying initiation by a year might have significant impacts in reducing alcohol misuse over the longer term [18]. Hence, substance misuse prevention programmes might usefully be offered whilst children are still at primary school before alcohol consumption (or regular consumption) starts. Our findings also highlight the importance of developmentally appropriate support for parents with adolescent children, in order to maximise protective factors linked to family functioning. While the CTC Youth Survey has previously been used in the UK to measure both young people's alcohol-related behaviours and pertinent risk and protective factors (such as the survey conducted in Plymouth, 
England) [50] the current study is the first to analyse the relationships between these aspects of the survey within a UK context.

Evidence from overseas studies indicating that increased parental monitoring is linked to a decrease in young people's alcohol misuse $[19,31,35,51,52]$ was supported by findings in this study. The role played by formal rule-setting and monitoring is ambiguous but seems likely to be only one element within an array of family interactions influencing children's alcohol use. Interestingly, a recent Hungarian study which examined protective factors for binge drinking among high school pupils found that although parental monitoring and acceptance of parents' values by adolescents (filial piety) were important, social support by parents and joint activities within families (such as eating dinner together) did not remain significant factors in final regression models [53]. The authors suggest that this may have been due both to cultural context (given that social support and joint activities were found to be protective factors in previous US studies), and the changing nature of parent-child relationships during adolescence.

Similarly, in the present study, family closeness was not a significant predictor after entry of parental monitoring. However, in the present study, parental monitoring and rule setting around alcohol was inseparable from more general communications regarding the child's behaviours, and was shown to be substantially higher amongst children who perceived a high degree of family closeness. Whilst not explicitly framed as a mediational analysis, the conditions for supporting a hypothesis of mediation according to Barron and Kenny [54] were all met in the present study. That is, i) the independent variable (family closeness) was associated with the outcome variables (self-reported drinking), ii) the independent variable was associated with the mediator variable (parental monitoring), iii) the mediator variable was associated with the outcome variables after controlling for the independent variable and iv) the association of the independent variable was eliminated by entry of the mediator variable. Hence, parental monitoring was perhaps an outcome of family closeness, which in turn predicted children's drinking behaviours. Such an interpretation is consistent with Stattin and Kerr's hypothesis that parental 'monitoring' may be linked to more open communication by children within close families [29].

Higher levels of parental monitoring were also associated with lower levels of violence and conflict, reduced likelihood of family history of substance misuse and less liberal attitudes towards alcohol and petty crime. Hence, parental monitoring appeared a practice typical to parents who modelled less antisocial behaviours and perhaps provided less opportunity for such behaviours. Whilst parental monitoring appears important, some research indicates that changing monitoring without considering the nature of family interactions which give rise to closer monitoring may be counterproductive [30]. Findings highlight the need for further exploration of the influence of family and wider cultural contexts on parental knowledge and regulation of children's behaviour. Parental monitoring remained a significant predictor of alcohol consumption after adjusting for all of these factors. Whilst beyond the remit of the present study, interactions between risk and protective factors, and the multiplicative impact of limited parental monitoring alongside higher levels of risk factors deserve closer scrutiny in future research.

A relationship was found here and elsewhere $[9,38,55]$ between increased alcohol misuse reported by young people and perceptions of more liberal parental attitudes towards consumption of alcohol and other substances and towards petty crime. Univariable models showed significant associations between family conflict and violence and children's drinking behaviour. However in multivariate models, associations of conflict and violence became non-significant. Hence, the relationship of family conflict and violence with young people's alcohol use may be confounded or possibly mediated, by other factors, rather than having the direct effect identified in other research [34]. Examination of the pathways through which family conflict and violence may impact children's drinking behaviours, whilst beyond the scope of this study, is an important direction for future research.

The finding that adolescent alcohol misuse was associated with family history of substance misuse problems was consistent with other research [41] as was the association with having a sibling who drank frequently before the age of 18 [43-45]. However the independence of these factors from other risk and protective factors contrasts somewhat with Kroll's review, which suggests that parental substance misuse influences children through its effects on family interactions [46] or via perceived parental attitudes [42]. The question in the CTC survey does not however ask specifically about parental substance misuse, and answers may refer to a variety of close or distant family members. A high number of responses referring to family members outside the parental home might account for the apparent independence of this influence, because residence elsewhere may have less effect on interactions between members occupying the same family home. This explanation might also account for a similar independent effect found for siblings who drank regularly before the age of eighteen, because data could refer to a brother or sister living in a different household from that of the respondent. The implications of these findings are difficult to estimate without information of the relationship to respondents, and the age and residence of such family members. In addition, given the 
cross sectional nature of the design, it is possible that other unmeasured aspects of family functioning mediate the impact of family role models.

Using the Social Development Model as a framework explained the main findings well. As previously described, the model proposes that interaction of children and young people with other family members forms the basis of attachments which may lead to adoption of prosocial or antisocial attitudes, beliefs and behaviour. Attachment to others who support prosocial behaviour through for example, close monitoring and communication between parent and child, may promulgate prosocial behaviour and reduce risk of alcohol misuse. Young people who form attachments to others who model behaviours such as substance misuse however, or are liberal in their attitudes towards misuse of alcohol or other substances by the child, will likely be at greater risk of developing more antisocial attitudes, beliefs and behaviour surrounding substance misuse.

Whilst many UK based interventions have been directed through the classroom, attention ought to be paid to supporting parenting behaviours which reduce children's risk of alcohol misuse. As the child grows older and develops social contacts outside the family, friends' approval becomes an important predictor of whether, and how much, the child drinks [37]. Nevertheless, parents' influence may remain much stronger than that of friends into late adolescence, particularly where family relationships are perceived by the child as close $[9,55]$. Prevention interventions need to address the broad determinants of alcohol consumption rather than focusing narrowly on raising children's awareness or increasing their knowledge about alcohol. Whilst the current study did not seek to make detailed policy recommendations, findings point to the need for a multifaceted approach to alcohol misuse prevention, encompassing school-based education, broad-based parenting and family programmes, treatment of substance misuse within families, and support services for families experiencing domestic violence. Such a range of services are likely to be provided by a range of different agencies, both within and without the substance misuse sector.

A number of future directions for research have been highlighted, including exploring the pathways through which family conflict and violence may predict alcohol consumption and the multiplicative impacts of risk factors. In addition, whilst this study has examined associations of children's perceptions of family functioning, future directions for research include exploring the extent of agreement between children's perceptions of family functioning and the reports of parents themselves, as well as associations of parental reports of parenting behaviours with children's drinking behaviours. Parents' may underestimate their children's drinking behaviour, particularly where communication between parent and child is limited, and hence children's self reports of drinking behaviour may offer greater validity than those of parents [56]. However, parents and young people may have very different perceptions of issues such as what constitutes rules and monitoring, and how strict or clear family rules are.

\section{Study strengths and limitations}

A number of strengths and limitations of the present study merit consideration. The study benefits from a large, representative sample of children within one Welsh city. Whilst using questionnaire items over whose design and administration the authors had no control, thorough factor analyses allowed for construction of independent variables which were both sufficiently related to the research questions and sufficiently distinct from one another to be considered as separate but inter-related constructs. Whilst somewhat strong associations (i.e. $r>$ 0.50) were observed between parental monitoring and two other variables (family closeness and parental attitudes to alcohol and petty crime), exploratory analyses indicated that these were not sufficiently inter-related to cause multicollinearity. Indeed, family closeness was not included in final models, whilst parental monitoring and parental attitudes to alcohol and petty crime remained significant independent predictors despite a large degree of shared variance.

However, it should be conceded firstly that data are cross sectional, and hence cause and effect cannot be demonstrated. Secondly, self report data is likely subject to social desirability biases. Thirdly, statistical analyses were limited by the removal of school-level identifiers from the dataset. This meant that it was not possible to assess or account for violations of the assumption of independence due to the hierarchical nature of the data sample. Cluster effects are related to the degree of intracluster correlation within the data, as well as the size of clusters, increasing as either of these factors becomes larger. Hence, the dataset, rather than including 6,000 independent units of analysis, is comprised of 12 clusters (i.e. schools) with an average size of 500 children per cluster. Given this large cluster size, even a small intra-cluster correlation would lead to large cluster effects. Therefore it is likely that associations are estimated with an artificially high level of certainty. Adjustment for clustering would not change odds ratio estimates, but would likely widen confidence intervals, leading some more borderline trends to become non-significant. Whilst the authors attempted to negotiate the reintegration of anonymised IDs, these requests were declined as the holders of the dataset had informed schools that they would be removed. Finally, somewhat variable response rates were observed across schools, due in large part to certain 
schools declining access to younger year groups, with implications for external validity. It was not possible to compare responses of children in schools with high or low response rates due to the aforementioned removal of school IDs. Furthermore, whilst efforts were made to minimise data loss by including all children who provided at least half complete responses on each scale, relatively large quantities of missing data were observed with boys and younger children slightly less likely to provide complete data, potentially introducing additional biases. Nevertheless, the study has demonstrated some compelling associations between children's perceptions of their family contexts and their own drinking behaviours.

\section{Conclusions}

This analysis confirms other findings of a strong association between family relationships and young people's alcohol misuse and also supports the hypotheses of the Social Development Model regarding the influence of parent-child interactions on young people's subsequent behaviour. Future programmes to reduce young people's alcohol misuse should target the families of young children, especially with respect to improving communication between parents and children. There is a need to look beyond classroom-based education and to assess what other support is available for families. This implies a requirement for multi-agency work to address a broad spectrum of support needs. Useful directions for further research would include exploration of the quality of family communication, particularly as it relates to explicit rule setting or more subtle regulation of children's behaviour; and how correlates of drinking behaviours are moderated by children's age.

\section{Competing interests}

The authors declare that they have no competing interests.

\section{Authors' contributions}

GM developed research questions, conducted data analysis and drafted sections of the manuscript. HR conducted the literature review and drafted sections of the manuscript. JS developed research questions, added to the literature review and contributed to revisions of manuscript drafts. All authors contributed to revisions of and approved the final manuscript.

\section{Acknowledgements}

We would like to thank Joanne Portwood and Jamie Smith for their help and support throughout the project, and Communities that Care for providing the dataset. The project funding was obtained from the Welsh Assembly Government's New Ideas Fund.

\section{Author Details}

Cardiff Institute of Society and Health, Cardiff School of Social Sciences, Cardiff University, 1-3 Museum Place, Cardiff, CF10 3BD UK

Received: 4 February 2010 Accepted: 22 April 2010

Published: 22 April 2010

\section{References}

1. Hawkins JD, Graham JW, Maguin E, Abbott R, Hill KG, Catalano RF: Exploring the effects of age of alcohol use initiation and psychosocial risk factors on subsequent alcohol misuse. J Stud Alcohol 1997, 58(3):280-290.

2. Hingson RW, Heeren T, Winter MR: Age at Drinking Onset and Alcohol Dependence: Age at Onset, Duration, and Severity. Arch Pediatr AdolesC Med 2006, 160(7):739-746.

3. Moffitt TE: Adolescence-Limited and Life-Course-Persistent Antisocial Behavior: A Developmental Taxonomy. Psychol Rev 1993, 100(4):674-701.

4. Advisory Council on the Misuse of Drugs: Pathways to Problems: Hazardous use of tobacco, alcohol and other drugs by young people in the UK and its implications for policy. Advisory Council on the Misuse of Drugs; 2006. [Place of publication not stated]

5. Jones SC, Gregory P: The impact of more visible standard drink labelling on youth alcohol consumption: Helping young people drink (ir)responsibly? Drug and Alcohol Review 2009, 28(3):230-234.

6. Anderson P, Baumberg B: Alcohol in Europe: A Public Health Perspective. London: Institute of Alcohol Studies; 2006.

7. Smith L, Foxcroft DR: Drinking in the UK: An Exploration of Trends. York: Joseph Rowntree Foundation; 2009.

8. Currie C, Nic Gabhainn S, Godeau E, Roberts C, Smith R, Currie D, Picket W, Richter M, Morgan A, Barnekow V: Inequalities in young people's health: HBSC international report from the 2005/2006 survey. Edinburgh: World Health Organization Regional Office for Europe; 2008.

9. Stead M, MacKintosh AM, McDermott L, Eadie D, MacNeil M, Stradling R, Minty S: Evaluation of the Effectiveness of Drug Education in Scottish Schools. Edinburgh: Scottish Executive Education Department; 2007.

10. The All Wales School Liaison Core Programme [http:// swanseapse.blogspot.com/2008/05/all-wales-school-liaison-coreprogramme.html]

11. McGrath $Y$, Sumnall H, Edmonds K, McVeigh J, Bellis MA: Review of grey literature on drug prevention among young people: Review summary. London: National Institute for Clinical Excellence; 2006.

12. Jones L, Sumnall H, Burrell K, McVeigh J, Bellis MA: Universal Drug Prevention. Liverpool: National Collaborating Centre for Drug Prevention; 2006

13. Bird HR, Canino GJ, Davies M, Zhang H, Ramirez R, Lahey BB: Prevalence and Correlates of Antisocial Behaviors Among Three Ethnic Groups. Abnorm Child Psychol 2001, 29(6):. 465(414)

14. Cernkovich SA, Giordano PC: Family Relationships and Delinquency. Criminology 1987, 25(2):295-322

15. Gil AG, Wagner EF, Vega WA: Acculturation, Familism, and Alcohol Use among Latino Adolescent Males: Longitudinal Relations. J Community Psychol 2000, 28(4):443-458.

16. Spoth RL, Redmond C, Trudeau L, Shin C: Longitudinal substance initiation outcomes for a universal preventive intervention combining family and school programs. Psychology of Addictive Behaviors 2002, 16(2):129-134

17. Dishion TJ, Kavanagh K: A multilevel approach to family-centered prevention in schools: Process and outcome. Addict Behav 2000, 25(6):899-911

18. Gruber E, DiClemente RJ, Anderson MM, Lodico M: Early Drinking Onset and Its Association with Alcohol Use and Problem Behavior in Late Adolescence. Prev Med 1996, 25(3):293-300.

19. Guo J, Hawkins JD, Hill KG, Abbott RD: Childhood and adolescent predictors of alcohol abuse and dependence in young adulthood. J Stud Alcohol 2001, 62(6):754-762.

20. Lloyd C, Joyce R, Hurry J, Ashton M: The Effectiveness of Primary School Drug Education. Drugs: education, prevention and policy 2000, 7(2):109-126.

21. Petrie J, Bunn F, Byrne G: Parenting programmes for preventing tobacco, alcohol or drugs misuse in children <18: a systematic review. Health Educ Res 2007, 22(2):177-191.

22. Cleveland MJ, Feinberg ME, Bontempo DE, Greenberg MT: The Role of Risk and Protective Factors in Substance Use Across Adolescence. $J$ Adolesc Health 2008, 43(2):157-164.

23. Catalano RF, Hawkins JD: The Social Development Model: A Theory of Antisocial Behavior. In Delinquency and Crime: Current Theories Edited by: Hawkins JD. Cambridge: Cambridge University Press; 1996:149-197.

24. Catalano RF, Park J, Harachi TW, Haggerty KP, Abbott RD, Hawkins JD: Mediating the Effects of Poverty, Gender, Individual Characteristics, and External Constraints on Antisocial Behavior: A Test of the Social Development Model and Implications for Developmental Life-Course 
Theory. In Integrated Developmental and Life-Course Theories of Offending Edited by: Farrington DP. New Brunswick: Transaction Publishers; 2005:93-123.

25. Vitaro F, Brendgen $M$, Tremblay RE: Influence of Deviant Friends on Delinquency: Searching for Moderator Variables. J Abnorm Child Psychol 2002, 28(4):313-325.

26. Schor EL: Adolescent alcohol use: social determinants and the case for early family-centered prevention. Family-focused prevention of adolescent drinking. Bull N Y Acad Med 1996, 73(2):335-356.

27. Beck KH, Shattuck T, Haynie D, Crump AD, Simons-Morton B: Associations between parent awareness, monitoring, enforcement and adolescent involvement with alcohol. Health Educ Res 1999, 14(6):765-775.

28. Dishion TJ, McMahon RJ: Parental Monitoring and the Prevention of Child and Adolescent Problem Behavior: A Conceptual and Empirical Formulation. Clinical Child and Family Psychology Review 1998, 1(1):61-75.

29. Stattin H, Kerr M: Parental Monitoring: A Reinterpretation. Child Dev 2000, 71(4):1072-1085.

30. Park J, Kosterman R, Hawkins JD, Haggerty KP, Duncan TE, Duncan SC, Spoth R: Effects of the "Preparing for the Drug Free Years" Curriculum on Growth in Alcohol Use and Risk for Alcohol Use in Early Adolescence.(Author abstract). Prevention Science 2000, 1(3): 125(114)

31. Cohen DA, Richardson J, LaBree L: Parenting Behaviors and the Onset of Smoking and Alcohol Use: A Longitudinal Study. Pediatrics 1994, 94(3):368-375.

32. Peterson PL, Hawkins JD, Catalano RF: Evaluating Comprehensive Community Drug Risk Reduction Interventions: Design Challenges and Recommendations. Eval Rev 1992, 16(6):579-602.

33. Anderson AR, Henry CS: Family System Characteristics and Parental Behaviors as Predictors of Adolescent Substance Use. Adolescence 1994, 29(114):

34. Webb JA, Baer PE: Influence of family disharmony and parental alcohol use on adolescent social skills, self-efficacy, and alcohol use. Addict Behav 1995, 20(1):127-135.

35. Ary DV, Duncan TE, Duncan SC, Hops H: Adolescent problem behavior: the influence of parents and peers. Behav Res Ther 1999, 37(3):217-230

36. Farrington DP: The Twelfth Jack Tizard Memorial Lecture. J Child Psychol Psychiatry 1995, 36(6):929-964.

37. Young $R$, Sweeting $H$, West $P$ : A longitudinal study of alcohol use and antisocial behaviour in young people. Alcohol 2008, 43(2):204-214.

38. Bahr SJ, Hoffman JP, Yang X: Parental and Peer Influences on the Risk of Adolescent Drug Use. The Journal of Primary Prevention 2005, 26(6):529-551.

39. McDermott D: The relationship of parental drug use and parents' attitude concerning adolescent drug use to adolescent drug use. Adolescence 1984, 19(1):89-97.

40. Ellickson SL, Tucker JS, Klein DJ, McGuigan KA: Prospective risk factors for alcohol misuse in late adolescence. J Stud Alcohol 2001, 62(6):773-782.

41. Gabel S, Stallings MC, Young SE, Schmitz S, Crowley TJ, Fulker DW: Family variables in substance-misusing male adolescents: the importance of maternal disorder. Am J Drug Alcohol Abuse 1998, 24(1):61-84.

42. Orford J: Excessive Appetities: a psychological view of addictions Chichester: John Wiley \& Sons; 1985

43. Bellis M, Hughes $K$, Morleo M, Tocque $K$, Hughes $S$, Allen T, Harrison D, FeRodriguez E: Predictors of risky alcohol consumption in schoolchildren and their implications for preventing alcohol-related harm. Substance Abuse Treatment, Prevention, and Policy 2007, 2(1):15.

44. Trim RS, Leuthe $E$, Chassin L: Sibling Influence on Alcohol Use in a Young Adult, High-Risk Sample. J Stud Alcohol 2005, 67(3):391-398.

45. Rakt M van de, Apel PNR: Association of criminal convictions between family members: Effects of siblings, fathers and mothers. Criminal Behaviour and Mental Health 2009, 19(2):94-108.

46. Kroll B: Living with an elephant: Growing up with parental substance misuse. Child and Family Social Work 2004, 9(2):129-140.

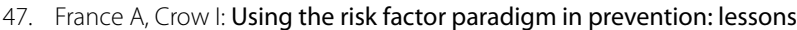
from the evaluation of Communities that Care. Children \& Society 2005, 19(2):172-184

48. Huston P, Naylor CD: Health services research: reporting on studies using secondary data sources. CMAJ: Canadian Medical Association Journal 1996, 155(12):1697.

49. 2010 Kansas Communities That Care Student Survey (Administration) [http://www.docstoc.com/docs/30795439/2010-KANSAS-COMMUNITIESTHAT-CARE-STUDENT-SURVEY-(Administration]
50. Communities That Care Youth Survey: Plymouth public schools [http:/ lesb.plymouth.k12.ma.us/attachments/2e3d9da3-cc55-4720-a79b793eb5219c40.pdf]

51. Arria A, Kuhn V, Caldeira K, O'Grady K, Vincent K, Wish E: High school drinking mediates the relationship between parental monitoring and college drinking: A longitudinal analysis. Substance Abuse Treatment, Prevention, and Policy 2008, 3(1):6.

52. Beck KH, Shattuck T, Haynie D, Crump AD, Simons-Morton B: Associations between parent awareness, monitoring, enforcement and adolescent involvement with alcohol. Health Educ Res 1999, 14(6):765-775.

53. Piko BF, Kovacs E: Do parents and school matter? Protective factors for adolescent substance use. Addict Behav 35(1):53-56

54. Baron RM, Kenny DA: The moderator-mediator variable distinction in social psychological research: conceptual, strategic, and statistical considerations. J Pers Soc Psychol 1986, 51(6):1173-1182.

55. Wood MD, Read JP, RE M, Brand NH: Do parents still matter? Parent and peer influences on alcohol involvement among recent high school graduates. Psychology of Addictive Behaviors 2004, 18(1):19-30.

56. Engels $\mathrm{R}$, Vorst $\mathrm{H}$ Van Der, Dekovic M, Meeus W: Correspondence in collateral and self-reports on alcohol consumption: A within family analysis. Addict Behav 2007, 32(5):1016-1030.

\section{doi: $10.1186 / 1747-597 X-5-6$}

Cite this article as: Moore et al., An exploratory study of the relationship between parental attitudes and behaviour and young people's consumption of alcohol Substance Abuse Treatment, Prevention, and Policy 2010, 5:6

\section{Submit your next manuscript to BioMed Central and take full advantage of:}

- Convenient online submission

- Thorough peer review

- No space constraints or color figure charges

- Immediate publication on acceptance

- Inclusion in PubMed, CAS, Scopus and Google Scholar

- Research which is freely available for redistribution 